\title{
Carotid body oxygen sensing
}

\author{
J. López-Barneo*,\#, P. Ortega-Sáenz",\#, R. Pardal*,\# , A. Pascual*,\# and J.I. Piruat*,\#
}

ABSTRACT: The carotid body $(C B)$ is a neural crest-derived organ whose major function is to sense changes in arterial oxygen tension to elicit hyperventilation in hypoxia. The CB is composed of clusters of neuron-like glomus, or type-I, cells enveloped by glia-like sustentacular, or type-II, cells. Responsiveness of $\mathrm{CB}$ to acute hypoxia relies on the inhibition of $\mathrm{O}_{2}$-sensitive $\mathrm{K}^{+}$ channels in glomus cells, which leads to cell depolarisation, $\mathrm{Ca}^{2+}$ entry and release of transmitters that activate afferent nerve fibres. Although this model of $\mathrm{O}_{2}$ sensing is generally accepted, the molecular mechanisms underlying $\mathrm{K}^{+}$channel modulation by $\mathrm{O}_{2}$ tension are unknown. Among the putative hypoxia-sensing mechanisms there are: the production of oxygen radicals, either in mitochondria or reduced nicotinamide adenine dinucleotide phosphate oxidases; metabolic mitochondrial inhibition and decrease of intracellular ATP; disruption of the prolylhydroxylase/ hypoxia inducible factor pathway; or decrease of carbon monoxide production by haemoxygenase-2. In chronic hypoxia, the СВ grows with increasing glomus cell number. The current authors have identified, in the $C B$, neural stem cells, which can differentiate into glomus cells. Cell fate experiments suggest that the The CB appears to be involved in the pathophysiology of several prevalent human diseases.

KEYWORDS: Acute hypoxia, carotid body, chronic hypoxia, ion channels, oxygen sensing, stem cells

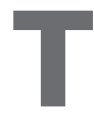
he carotid body (CB), a small neural crestderived paired organ located at the carotid bifurcation (fig. 1a), is a principal component of the homeostatic acute oxygen-sensing system required to activate the brainstem respiratory centre to produce hyperventilation during hypoxaemia (e.g. in high-altitude residents or in patients with chronic obstructive pulmonary diseases) [2-4]. The $\mathrm{CB}$ is one of the most irrigated organs in the body and receives blood through a branch arising from the external carotid artery. The CB parenchyma is organised into glomeruli: clusters of cells, in close contact with a profuse network of capillaries, and afferent sensory fibres joining the glossopharyngeal nerve (fig. 1a and b). The most abundant cell types in the $\mathrm{CB}$ glomeruli are the neuron-like glomus, or type-I, cells, which are enveloped by processes of glia-like, sustentacular type-II cells (fig. 1c). The $\mathrm{CB}$ also contains some autonomic neurons and fibres, which seem to have an efferent regulatory action on glomus cells [5].
Glomus cells are physiologically complex, as they express a broad variety of voltage- and ligandgated ion channels, as well as transient receptor potential and background $\mathrm{K}^{+}$channels. They contain secretory vesicles packed with neurotransmitters, notably ATP, dopamine and acetylcholine, among others [6]. Voltage-gated ion channels have been studied in detail in patchclamped glomus cells from several species [2]. Macroscopic ionic currents recorded from these cells are composed of outward (mediated by several classes of $\mathrm{K}^{+}$channels) and inward (mediated by $\mathrm{Na}^{+}$and/or $\mathrm{Ca}^{2+}$ channels) components (as discussed hereunder). Quantitatively, the proportion of the different subtypes of $\mathrm{K}^{+}$, $\mathrm{Na}^{+}$and $\mathrm{Ca}^{2+}$ channels expressed in glomus cells greatly varies among the mammalian species studied. Owing to the presence of voltage-gated membrane channels, glomus cells are electrically excitable and can repetitively generate action potentials. This property is particularly evident in rabbit glomus cells, with relatively large

\section{AFFILIATIONS}

*Instituto de Biomedicina de Sevilla (IBiS), Hospital Universitario Virgen del Rocío/CSIC/Universidad de Sevilla, Sevilla, and

${ }^{*}$ Centro de Investigación Biomédica en Red sobre Enfermedades Neurodegenerativas (CIBERNED), Spain

\section{CORRESPONDENCE}

J. López-Barneo

Instituto de Biomedicina de Sevilla Edificio de Laboratorios

Segunda planta

Hospital Universitario Virgen del Rocío

Avenida Manuel Siurot s/n 41013 Sevilla

Spain

Fax: 34954617301

E-mail: Ibarneo@us.es

Received:

April 142008

Accepted after revision:

April 222008

SUPPORT STATEMENT

This research has been supported by the Spanish Ministry of Health (Instituto de Salud Carlos III), The Spanish Ministry of Science, and the Juan March and Marcelino Botín Foundations.

STATEMENT OF INTEREST

None declared.

Previous articles in this series: No. 1: Wagner PD. The biology of oxygen. Eur Respir J 2008; 31: 887-890. No. 2: Zhou G, Dada LA, Sznajder Jl. Regulation of alveolar epithelial function by hypoxia. Eur Respir J 2008; 31: 1107-1113. No. 3: Berchner-Pfannschmidt U, Frede S, Wotzlaw C, Fandrey J. Imaging of the hypoxia-inducible factor pathway: insights into oxygen sensing. Eur Respir J 2008; 32: 210-217. No. 4: Lévy P, Pépin J-L, Arnaud C, et al. Intermittent hypoxia and sleep-disordered breathing: curent concepts and perspectives. Eur Respir J 2008; 32: 1082-1095.

European Respiratory Journal Print ISSN 0903-1936 Online ISSN 1399-3003 
voltage-dependent $\mathrm{Na}^{+}$currents [7]. Glomus cell membrane depolarisation induces a reversible neurosecretory response, dependent on extracellular $\mathrm{Ca}^{2+}$ influx, which can be easily monitored by amperometry $[8,9]$. Thus, glomus cells behave as presynaptic-like elements that establish contact with the postsynaptic sensory nerve fibres.

The precise functional significance of the numerous neurotransmitters that exist in the CB is still under debate. The CB is among the most dopaminergic structures in the body and, as extracellular dopamine inhibits the $\mathrm{Ca}^{2+}$ channels in glomus cells, it has been suggested that this transmitter has an autocrine role [10]. In contrast, ATP and, possibly, acetylcholine appear to be the major active neurotransmitters at the glomus cell-afferent fibre synapse [6, 11]. There are other amines and several neuropeptides in the CB whose functional significance is, as yet, not well known. Glomus cells also have high levels of neurotrophic factors, which seem to exert a local autocrine and paracrine action [12]. Among these factors, the glia cell line-derived neurotrophic factor (GDNF) has attracted particular attention because it is highly expressed in adult glomus cells [13-15]. As GDNF can promote the survival of dopaminergic neurons, $\mathrm{CB}$ transplants have been used for intrastriatal delivery of dopamine and GDNF in parkinsonian animal models and in some pilot clinical studies on Parkinson's disease patients (see section Carotid body function and mechanisms of disease).

Of the cells in the CB parenchyma, $\sim 15-20 \%$ are type-II cells, which in vivo exhibit long processes surrounding type-I cells (fig. $1 \mathrm{~b}$ and $\mathrm{d}$ ). Type-II cells are nonexcitable and lack most of the voltage-gated channels characteristic of type-I cells $[7,16]$. The molecular interactions between type-I and type-II cells, possibly critical for the physiology of the organ, are basically unknown. Classically, type-II cells were considered to belong to the peripheral glia with a supportive role. However, recent experimental data have shown that the adult CB is a functionally active germinal niche. In this regard, it has been strongly suggested that type-II cells are indeed dormant stem cells that in response to physiological hypoxia can proliferate and differentiate into new glomus cells (see section Carotid body plasticity in chronic hypoxia: adult carotid body stem cells) [1].

\section{RESPONSES OF GLOMUS CELLS TO ACUTE HYPOXIA: MODEL OF CAROTID BODY $\mathrm{O}_{2}$ SENSING}

Glomus cells are polymodal arterial chemoreceptors, activated not only by hypoxia but also by other stimuli, most notably hypercapnia, extracellular acidosis and hypoglycaemia [2, 17]. It is, however, the sensitivity to acute changes of $\mathrm{O}_{2}$ tension what makes the $\mathrm{CB}$ essential for the classical adaptive hyperventilatory reflex in response to hypoxaemia. Although the function of the $\mathrm{CB}$ as an acute oxygen sensor has been known since the first half of the 20th century, it was during the past 15-20 yrs that the basic cellular events underlying this physiological process were unveiled. It is now broadly accepted that glomus cells are the chemoreceptive elements in the $\mathrm{CB}$ and that they contain several classes of $\mathrm{O}_{2}$-sensitive $\mathrm{K}^{+}$channels whose open probability decrease during hypoxia [2-4]. Voltage-dependent $\mathrm{K}^{+}$channels were initially reported to be $\mathrm{O}_{2}$ sensitive in rabbit $\mathrm{CB}$ cells [18], but other $\mathrm{K}^{+}$channel types (particularly $\mathrm{Ca}^{2+}$-dependent maxi- $\mathrm{K}^{+}$and twin pore acid-stimulated $\mathrm{K}^{+}$channel-like background channels) have been also found to be modulated by $\mathrm{O}_{2}$ in several $\mathrm{CB}$ preparations $[19,20]$. Inhibition of the $\mathrm{K}^{+}$channels leads to glomus cell membrane depolarisation and increase in the firing frequency of the cells, thus resulting in $\mathrm{Ca}^{2+}$ channel opening, transmembrane $\mathrm{Ca}^{2+}$ influx and transmitter release. The major steps in the chemotransduction process are: hypoxic inhibition of the $\mathrm{K}^{+}$currents (fig. 2a) and inhibition of single $\mathrm{K}^{+}$channel activity (fig. 2b) $[18,21]$, external $\mathrm{Ca}^{2+}$-dependent increase of cytosolic $\mathrm{Ca}^{2+}$ in hypoxia (fig. 2c) $[8,23]$, and catecholamine release from hypoxic glomus cells (fig. 2d) [8, 9]. The dosedependent cellular responses to hypoxia (increase of cytosolic $\mathrm{Ca}^{2+}$ concentration and catecholamine release) almost perfectly match the characteristic hyperbolic correlation between arterial $\mathrm{O}_{2}$ tension and the afferent discharges of the $\mathrm{CB}$ sinus nerve or the increase in ventilation seen in vivo. Within the context of this broadly accepted "membrane model" of $\mathrm{CB} \mathrm{O}_{2}$ sensing, schematically summarised in figure 3 , it is worth remarking
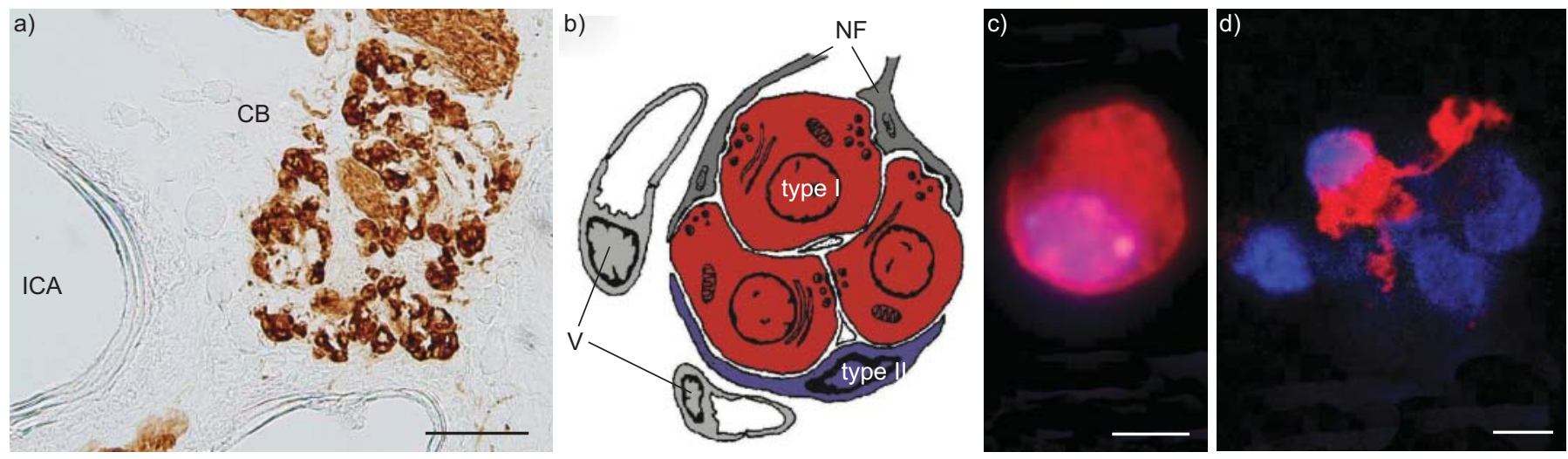

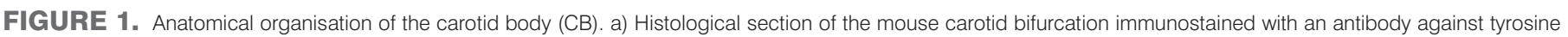

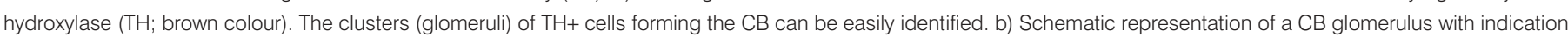

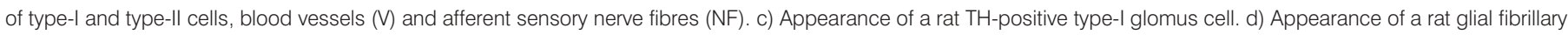

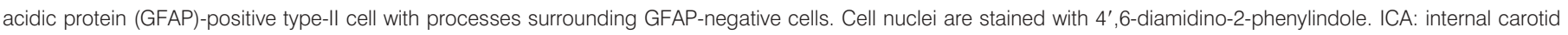
artery. Scale bars $=100 \mu \mathrm{m}$ (a) and $5 \mu \mathrm{m}$ (c and d). Modified from [1] 
that, although the participation of mitochondria in $\mathrm{CB} \mathrm{O}_{2}$ sensing is under debate (see section Mechanisms of carotid body acute $\mathrm{O}_{2}$ sensing), the experimental data available unequivocally indicate that they do not contribute to the hypoxia-induced rise of cytosolic $\mathrm{Ca}^{2+}$ concentration necessary to trigger glomus cell secretion.

The membrane model of $\mathrm{CB}$ oxygen sensing discussed in the preceding paragraph has been generalised to other neurosecretory or contractile cells acutely responding to hypoxia. Among those are neonatal adrenomedullary chromaffin cells [25-27], cells in the neuroepithelial bodies of the lung [28] or PC12 cells [29], as well as pulmonary arterial myocytes [30, 31]. These cells belong to the homeostatic acute $\mathrm{O}_{2}$-sensing system that allows mammalian fast adaptation to hypoxic environments [4].

\section{MECHANISMS OF CAROTID BODY ACUTE $\mathrm{O}_{2}$ SENSING}

Despite progress in $\mathrm{CB}$ cellular physiology, the molecular mechanisms underlying glomus cell $\mathrm{O}_{2}$ sensing, i.e. how the change in $\mathrm{O}_{2}$ tension is translated into decrease of $\mathrm{K}^{+}$ conductance, remain essentially unknown. Several possible $\mathrm{O}_{2}$-sensing mechanisms, including the direct interaction of $\mathrm{O}_{2}$ with the ion channels or their indirect modulation through $\mathrm{O}_{2}-$ sensing molecules, have been postulated [2, 24]. Since numerous $\mathrm{K}^{+}$channel types have been reported to be $\mathrm{O}_{2}$ sensitive, it is assumed that there could be several $\mathrm{O}_{2}$ sensors coexisting in the same cell or distributed among the different $\mathrm{O}_{2}$-sensitive cell types, even in closely related animal species. Understanding $\mathrm{CB} \mathrm{O}_{2}$ sensing at the molecular level is, however, challenged by the small size of the organ, which precludes elaborated biochemical and molecular biology experiments, and the gaseous nature of the detected molecule, which is easily diffusible across cell membranes and difficult to keep under strict control in the open chambers normally used for in vitro studies. In addition, $\mathrm{O}_{2}$ responsiveness of isolated $\mathrm{CB}$ glomus cells is often lost, because of damage during the vigorous enzymatic and mechanical treatment needed for their dispersion. Finally, some possible $\mathrm{O}_{2}$-sensing mechanisms have been inferred from pharmacological experiments using compounds (as, for example, mitochondrial inhibitors) that might have nonspecific effects [32, 33], hence providing misleading conclusions. The mechanisms of $\mathrm{CB} \mathrm{O}_{2}$ sensing are summarised in the following sections, emphasising the proposals that are currently under debate and the knowledge generated by the current authors' experimental work.

\section{Redox-based $\mathrm{O}_{2}$ sensor: reduced nicotinamide adenine dinucleotide phosphate oxidase}

A plausible form of $\mathrm{CB} \mathrm{O}_{2}$ sensing is the conversion of $\mathrm{O}_{2}$ into reactive oxygen species (ROS), which would in turn alter the redox status of signalling molecules and the function of membrane ion channels. The two ROS-producing sites postulated as $\mathrm{O}_{2}$ sensors are the reduced nicotinamide adenine dinucleotide phosphate (NADPH) oxidase and mitochondria systems.

NADPH oxidase is found in neutrophils and histochemically localised in the $C B$, although its presence in the chemosensitive glomus cells is not well documented. This enzyme has been proposed to transduce $\mathrm{O}_{2}$ levels by changing the rate of superoxide anion production, which, after conversion to hydrogen peroxide, oxidises ion channels and other molecules. The neutrophil oxidase is an oligomer composed of the membrane-bound catalytic complex (formed by gp91phox and p22phox), a cytochrome, and several cytosolic regulatory subunits ( $\mathrm{p} 47$ phox and others). Although impaired $\mathrm{O}_{2}$ sensitivity of airway chemoreceptor cells has been reported in a)

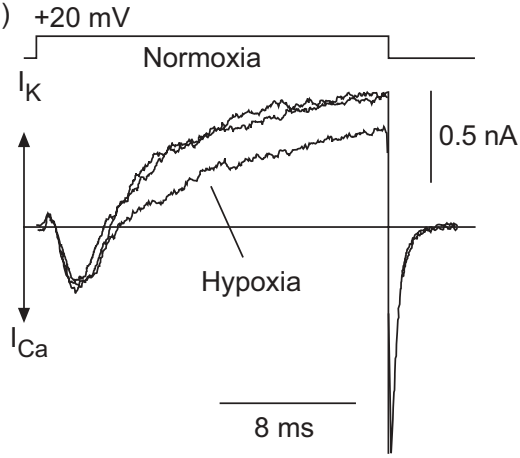

b) Normoxia

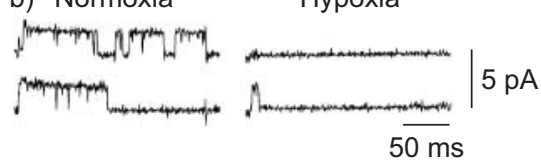

c)

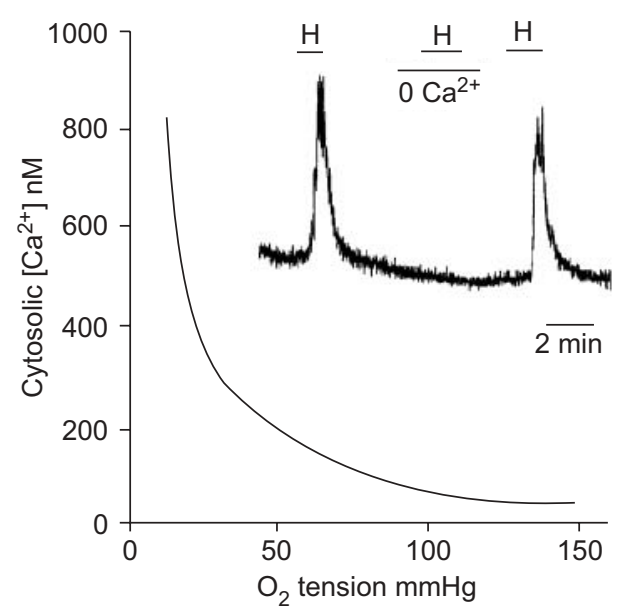

d)

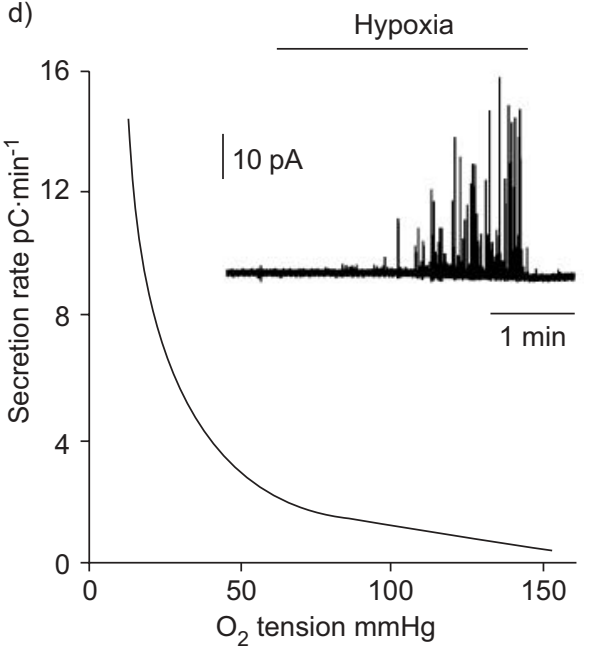

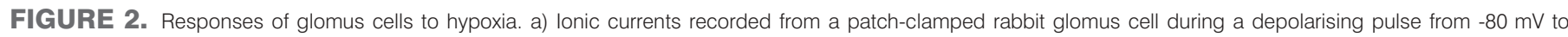

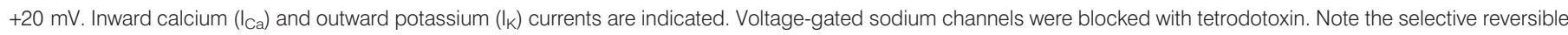

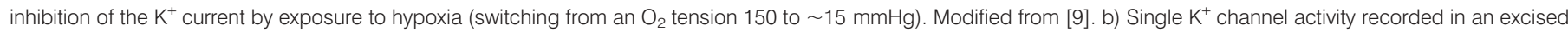

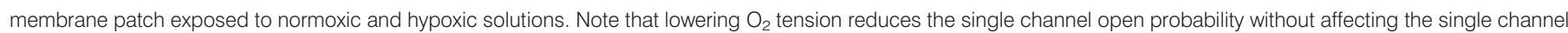

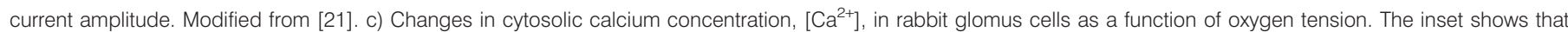

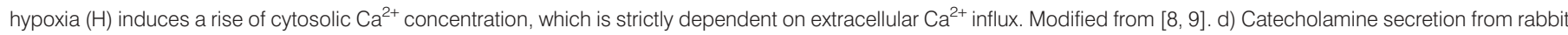
glomus cells as a function of oxygen tension. The inset illustrates the secretory response of a single cell to hypoxia as monitored by amperometry. Modified from [22]. 


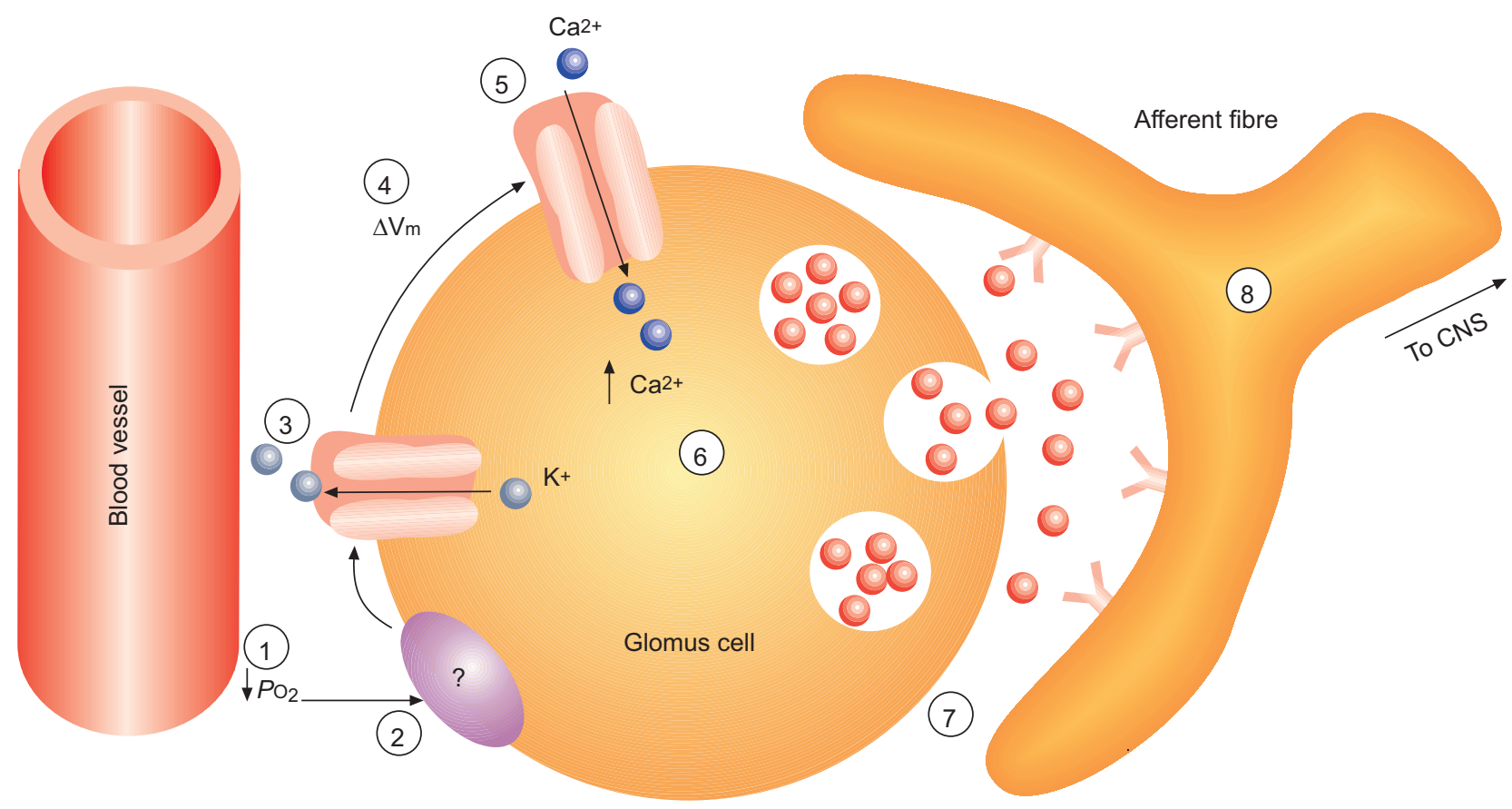

FIGURE 3. Membrane model of glomus cell oxygen sensing. The steps in chemosensory transduction are as follows. 1) Decrease of $\mathrm{O}_{2}$ tension $\left(\mathrm{PO}_{2}\right)$, 2) $\mathrm{O}_{2}$ sensing, 3) closure of potassium channels, 4) cell depolarisation, 5) opening of calcium channels, 6) increase of cytosolic calcium concentration, [C $\left.{ }^{2+}\right]$, 7) transmitter release and 8) activation of afferent fibres, which send the information to the central nervous system (CNS). Although these steps in chemosensory transduction have broad experimental support, the nature of the $\mathrm{O}_{2}$ sensor and the mechanisms by which changes in $\mathrm{O}_{2}$ tension regulate $\mathrm{K}^{+}$channel activity are still unknown (question mark). $\Delta \mathrm{Vm}$ : change in membrane voltage. Modified from [2, 24].

gp91phox-null mutant mice [34], hypoxia responsiveness of CB and other cells appears to be unaltered $[35,36]$. Moreover, in patch-clamped glomus cells from these animals the modulation of the $\mathrm{O}_{2}$-sensitive $\mathrm{K}^{+}$current by $\mathrm{O}_{2}$ tension is unchanged [37]. Surprisingly, genetic suppression of another component of the neutrophil's oxidase (p47phox) results in mice with increased basal activity in the carotid sinus nerve and exacerbated ventilatory response to hypoxia [38]. This phenotype suggests nonspecific modifications in the p47phox knockout mouse rather than the selective alteration of the $\mathrm{O}_{2}$-sensing machinery in the CB cells. Altogether, these studies indicate that the phagocytic NADPH oxidase is not directly involved in $\mathrm{CB} \mathrm{O}_{2}$ sensing, although it is conceivable that other isoforms, existing in numerous tissues [39], could contribute to the hypoxia responsiveness of $\mathrm{CB}$ cells. The entire concept of redox-based $\mathrm{O}_{2}$ sensing in glomus cells is, however, challenged by the finding that the reduced/oxidised glutathione ratio in CBs remains unchanged during exposure to hypoxia, despite the fact that this quotient increases after incubation of CBs with $\mathrm{N}$-acetylcysteine, a precursor to reduced glutathione and an ROS scavenger [40].

\section{Mitochondrial dysfunction}

Several investigators have traditionally considered mitochondria to be the site of $\mathrm{O}_{2}$ sensing in glomus cells because, similar to hypoxia, inhibitors of the electron transport chain (ETC) or mitochondrial uncouplers increase the afferent activity of the CB sinus nerve [41]. This proposal was complemented by reports that hypoxia and cyanide (an inhibitor of mitochondrial complex IV) lead to $\mathrm{Ca}^{2+}$ release from mitochondria in dispersed glomus cells [42]. As indicated in the previous section, the mitochondrial hypothesis of $\mathrm{CB} \mathrm{O}_{2}$ sensing has lost much support after the discovery of $\mathrm{O}_{2}$-regulated $\mathrm{K}^{+}$channels and experimental demonstration that the $\mathrm{Ca}^{2+}$ ions needed for glomus cell secretion in hypoxia enter the cell via plasmalemmal voltage-gated $\mathrm{Ca}^{2+}$ channels $[8,9,23]$. The interest in mitochondria has, however, resurged more recently because mitochondria uncouplers raise cytosolic $\mathrm{Ca}^{2+}$ and reduce background $\mathrm{K}^{+}$permeability in glomus cells $[43,44]$. So, it could be that in hypoxia, mitochondria generate signals that alter membrane ionic conductances (e.g. through modification of the cell redox status or via reduction of cytosolic ATP). In fact, it has been proposed that the redox modulation of membrane $\mathrm{K}^{+}$channels is the reason for the $\mathrm{O}_{2}$ sensitivity of other acutely responding cells [45]. Conversely, decrease of intracellular ATP in hypoxia could result in either the direct closure of ATP-regulated background $\mathrm{K}^{+}$channels [46] or the increase in AMP/ATP ratio leading to AMP kinase activation. AMP kinase could, in turn, modulate membrane ion channels thus eliciting cell depolarisation [47]. In favour of this hypothesis is the existence of $\mathrm{O}_{2}$-sensitive background $\mathrm{K}^{+}$ channels, which appear to be modulated by mitochondrial uncouplers and ATP. In addition, mRNA of AMP kinase is detected in glomus cells (unpublished data of the current authors). In contrast with these observations, the current authors have shown that in the presence of saturating concentrations of mitochondria ETC inhibitors acting at different complexes (I, II, III and IV), hypoxia can still activate transmitter release from glomus cells, thus suggesting that mitochondrial inhibition and hypoxia might activate glomus cells through separate pathways [32]. Moreover, patchclamped glomus cells loaded with a high concentration of 
Mg-ATP (3-5 mM) still respond to hypoxia [8, 18]. Interestingly, the current authors have also observed that rotenone, but no other agents inhibiting complex I at different sites, can block hypoxia responsiveness of glomus cells, thus suggesting that a rotenone-binding site participates in $\mathrm{O}_{2}$ sensing [32]. This effect of rotenone seems to be quite specific, as glomus cell responsiveness to hypoglucaemia is unaffected by rotenone [48]. However, the pharmacological data must be interpreted with caution, as it is highly likely that at the concentrations used, ETC inhibitors have nonspecific effects on the voltage-gated ion channels [33]. It is known, for example, that rotenone can reversibly inhibit $\mathrm{K}^{+}$currents in cells devoid of mitochondria [49].

Mitochondria have also been associated with $\mathrm{CB} \mathrm{O}_{2}$ sensing because mutations in the mitochondrial complex II (particularly in the small membrane-anchoring subunit of succinate dehydrogenase (SDHD)) are the main cause of familiar hereditary paraganglioma (PGL), a highly vascularised and often catecholamine-secreting CB tumour [50]. As PGLs display cellular hyperplasia/anaplasia similar to the $\mathrm{CB}$ of individuals exposed to chronic hypoxaemia [51,52], it has been proposed that the ultimate cause of tumorigenesis is a defect in sensing environmental $\mathrm{O}_{2}$ levels [50, 53-55]. The current authors have tested this hypothesis by generating a knockout mouse model lacking SDHD. Whereas null animals die early during embryonic life, heterozygous $S D H D+/-$ mice develop normally without apparent signs of respiratory distress. SDHD+/- animals show, however, a $40-50 \%$ decrease of mitochondrial complex II activity in all the tissues tested (brain, liver, heart and kidney) and a small ( $15 \%)$ increase in the number and size of glomus cells [56]. Despite these structural changes, the response to hypoxia of glomus cells in $S D H D+/-$ mice was unaltered, or even augmented, in comparison with $S D H D+/+$ litter mates, indicating that partial deficiency of complex II activity does not seem to alter glomus cell responsiveness to hypoxia.

In summary, although the exact role of mitochondria in $\mathrm{CB}$ function is not fully clarified, the data available thus far suggest that these organelles do not directly contribute to the primary steps in $\mathrm{CB} \mathrm{O}_{2}$ sensing. However, mitochondrial dysfunction (e.g. in extreme hypoxia or after addition of ETC inhibitors) might result in metabolic alterations leading to changes in membrane ion channels that could modulate glomus cell activity. In accord with this idea, glomus cells in partially deficient SDHD mice $(S D H D+/-)$, although with normal $\mathrm{O}_{2}$ sensing, exhibit an abnormally high resting secretory activity and a constitutive $\sim 50 \%$ reduction in total $\mathrm{K}^{+}$current density [56].

\section{Prolyl/asparagyl hydroxylases and hypoxia-inducible factor pathway}

The best-studied $\mathrm{O}_{2}$ sensors are probably the prolyl/asparagyl hydroxylases, enzymes that utilise molecular $\mathrm{O}_{2}$ (together with $\mathrm{Fe}^{2+}$ and $\alpha$-ketoglutarate as cosubstrate) to hydroxylate specific proline/asparagine residues, respectively, of hypoxia-inducible transcription factors (HIF)- $1 \alpha$, and its isoforms, as well as other molecules which, in turn, regulate the expression of numerous hypoxia-sensitive genes. In the absence of $\mathrm{O}_{2}$, the lack of hydroxyl groups in specific proline and asparagine residues of the HIF molecule prevents its degradation by the proteasome and facilitates its stabilisation, dimerisation with HIF-1 $\beta$, translocation to the nucleus, and transcriptional activity $[57,58]$. Hydroxylation of HIF in the presence of $\mathrm{O}_{2}$ occurs in a few minutes, hence it is conceivable that $\mathrm{O}_{2}$-dependent hydroxylases could also modulate ion channels and thus participate in the acute responses to hypoxia. The current authors have tested this plausible hypothesis using CB slices incubated with saturating concentrations of dimethyloxalylglycine (DMOG), a membrane-permeant competitive inhibitor of $\alpha$ ketoglutarate that completely and nonselectively inhibits hydroxylases [59]. It is well known that DMOG mimics hypoxia and induces the expression of HIF-dependent genes [59, 60]. However, after incubation of CB slices with DMOG, glomus cells retain their normal responsiveness to acute hypoxia. Preliminary experiments on prolyl hydroxylase 3-null mice performed in the current authors' laboratory have also shown that their CB sensitivity to acute hypoxia is unaltered.

It has also been suggested that HIF-1 $\alpha$ could directly participate in the acute responsiveness to hypoxia, since the plastic changes in the chemosensory activity (augmented ventilatory response and long-term facilitation) induced by sustained and intermittent chronic hypoxia are altered in HIF$1 \alpha+/$ - mice [61, 62]. CB cells in slices from HIF-1 $\alpha+/-$ mice show, however, a marked secretory response to hypoxia indistinguishable from that measured in homozygous HIF$1 \alpha+/+$ wild-type mice [63]. These data suggest that, although HIF-1 $\alpha$ may contribute to CB functional plasticity, partial deficiency of the transcription factor does not significantly alter the intrinsic acute $\mathrm{O}_{2}$ sensitivity of $\mathrm{CB}$ glomus cells.

\section{Haemoxygenase-2}

Haemoxygenase (HO)-2 is an antioxidant enzyme constitutively expressed in most cells, including CB cells [64-66]. This enzyme uses $\mathrm{O}_{2}$ to convert haem into biliverdin, iron and carbon monoxide [67]. The possible involvement of $\mathrm{HO}-2$ in $\mathrm{CB}$ acute $\mathrm{O}_{2}$ sensing has been suggested because it co-immunoprecipitates with heterologously expressed maxi- $\mathrm{K}^{+}$channels and its inhibition with small interfering RNA abolishes the $\mathrm{O}_{2}$ modulation of recombinant channels [65]. HO-2 is expressed in rat $\mathrm{CB}$ glomus cells and, in addition, native maxi- $\mathrm{K}^{+}$channels recorded in patches excised from these cells are activated by HO-2 substrates (haem and NADPH). Based on these data it has been proposed that $\mathrm{HO}-2$ could act as an $\mathrm{O}_{2}$ sensor through the production of $\mathrm{CO}$, which is by itself a maxi- $\mathrm{K}^{+}$ channel activator $[67,68]$.

Although the proposal that $\mathrm{HO}-2$ participates in $\mathrm{O}_{2}$ sensing is quite attractive [69] it has been challenged by experiments performed on the HO-2 knockout mouse, which develop normally, without alteration in haematocrit or signs of respiratory distress during the first postnatal 2-3 months, although they manifest cardiorespiratory alterations at advanced age [67, 70]. The current authors have studied in detail the secretory responses to acute hypoxia of glomus cells from $\mathrm{HO}-2+/+$, $\mathrm{HO}-2-/-$ and $\mathrm{HO}-2+/-$ animals using $\mathrm{CB}$ slices $[63,22]$. In all cases, secretion rate increased drastically upon exposure to low $\mathrm{O}_{2}$ tension. The dose-response curves obtained from glomus cells exposed to different $\mathrm{O}_{2}$ tensions were indistinguishable in HO-2-deficient and wild-type mice, suggesting that partial or complete $\mathrm{HO}-2$ deficiency do not alter glomus cell $\mathrm{O}_{2}$ sensitivity. It can be also disregarded that 
the embryonic absence of HO-2 is compensated by upregulation of HO-1, an inducible $\mathrm{HO}$, since the mRNA expression of this enzyme in $\mathrm{CB}$ tissue from HO-2-null animals is not significantly increased. Moreover, $\mathrm{HO}-1$ does not seem to compensate for HO-2 deficiency, since within the $\mathrm{CB}$ it is expressed predominantly in blood vessels and, even in $\mathrm{HO}-2-/-$ animals, it is absent from the clusters (glomeruli) of tyrosine hydroxylase $(\mathrm{TH})+$ glomus cells [22].

Although glomus cell responsiveness to hypoxia is normal in HO-2-null animals, it seems that HO-2 deficiency causes CB phenotypic alterations secondary to redox dysregulation [65]. HO-2-null young adults ( $<3$ months) showed a marked upregulation of cyclophilin and $\mathrm{TH}$, the rate-limiting enzyme for catecholamine synthesis highly expressed in $\mathrm{CB}$ glomus cells. In contrast, CB Slo1 mRNA (the maxi-K $\mathrm{K}^{+}$channel $\alpha$ subunit gene) was significantly downregulated in HO-2-null mice in comparison with controls. These alterations in the CB gene expression profile, although unrelated to the mechanisms of $\mathrm{CB} \mathrm{O}_{2}$ sensing, are compatible with a subclinical cellular oxidative stress, which could also be responsible for a small, but significant, CB growth observed in HO-2-null animals [22].

In summary, no definitive conclusion can be drawn to date regarding the molecular mechanisms of $\mathrm{CB} \mathrm{O}$ sensing. There are numerous hypotheses and interesting proposals under debate but clarification of this important physiological process must await future experimental work.

\section{CAROTID BODY PLASTICITY IN CHRONIC HYPOXIA: ADULT CAROTID BODY STEM CELLS}

In addition to its role as an acutely responding arterial chemoreceptor, the $\mathrm{CB}$ is special among the adult neural and paraneural organs because it grows several-fold upon exposure to chronic hypoxia. In humans, this adaptive response occurs during acclimation to high altitude [52, 71, 72] or in patients suffering cardiopulmonary diseases presenting hypoxaemia [51, 73] (see section Carotid body function and mechanisms of disease). The current authors have recently studied in detail the morphological changes induced by chronic hypoxia in mouse and rat $\mathrm{CB}$, with the aim of identifying the progenitors that could be used for in vitro expansion of CB dopaminergic glomus cells [1]. Mouse CBs from animals kept in normoxia $\left(21 \% \mathrm{O}_{2}\right.$ atmosphere) show the typical histological organisation of the organ with clusters of $\mathrm{TH}+$ glomus cells (fig. 4a). Exposure of the animals to hypoxia $\left(10 \% \quad \mathrm{O}_{2}\right.$ atmosphere) induces a marked $\mathrm{CB}$ enlargement caused by dilation and multiplication of blood vessels, as well as expansion of the parenchyma, with increased number of $\mathrm{TH}+$ glomus cell clusters (fig. $4 \mathrm{~b}$ ). To analyse the origin and formation of new glomus cells, mice were treated with BrdU (a marker selectively incorporated in replicating DNA) and, subsequently, maintained several days in a hypoxic environment. After a few days in hypoxia, even before the CB growth became macroscopically obvious, numerous BrdU+ TH+ cells were observed, indicating the appearance of new glomus cells (fig. 4c). Brief (2-h) BrdU pulses were also applied to animals that had been kept in hypoxia for several days, in order to test whether some $\mathrm{TH}+$ cells could be captured in the process of division. In some of these experiments, $\mathrm{TH}+\mathrm{BrdU}+$ cells (fig. 4d) were observed, suggesting that, as reported previously [12], glomus cells might undergo mitosis upon activation by hypoxia. $\mathrm{TH}+$ glomus cells cannot produce clonal neurospheres in vitro (as discussed hereunder), so it is likely that their mitogenic potential is limited and possibly depends on the level of hypoxia and animal age [1]. The time course of CB structural changes induced by hypoxia is shown in figure 4e. Although BrdU incorporation into the CB tissue is observed immediately after exposure to hypoxia, the newly formed glomus cells (BrdU+ $\mathrm{TH}+$ ) were predominantly seen after few days. This time course also suggested the existence in the $\mathrm{CB}$ of precursors, whose proliferation in hypoxia precedes their differentiation into glomus cells.

The precursors giving rise to glomus cells have been identified using enzymatically dispersed CB cells plated in floating conditions. To stimulate clonogenic proliferation, cells are cultured under moderate hypoxia $\left(3 \% \mathrm{O}_{2}\right)$, a condition that mimics the hypoxic stimulation of $\mathrm{CB}$ growth in vivo. Under these conditions, $\sim 1 \%$ of the plated $\mathrm{CB}$ cells give rise to neurospheres, typical colony-like structures formed by growing neural stem cells (fig. 5a and b). In contrast to the typical spherical shape of neurospheres formed by stem cells isolated from other neural (central or peripheral) areas [74, 75], most of the CB-derived neurospheres have characteristically one or two large blebs budding out of the main core (fig. $5 a$ and b). Immunocytochemical analysis of thin-section neurospheres have revealed the presence of nestin (a typical neural stem cell marker)-positive cells within the main core, and clusters of differentiated $\mathrm{TH}+$ and nestin- cells within the blebs attached through a hilus (fig. $5 \mathrm{c}$ and $\mathrm{d}$ ). The $\mathrm{TH}+$ blebs resembled in shape the glomeruli characteristic of the in situ CB and grew to a large size after several weeks in culture (fig. 5e). This morphological and immunological pattern (core of nestin+ cells preceding the blebs with $\mathrm{TH}+$ cells) is consistently observed in most of the CB neurospheres studied (fig. 5f-h). The clonal origin of $\mathrm{CB}$ neurospheres has been confirmed by single cell deposition experiments (fig. 5i-k).

The data described in the previous section indicate that the $\mathrm{CB}$ contains stem cells from which $\mathrm{TH}+$ cells (resembling glomus cells) can be differentiated in vitro. The current authors have studied the physiology of stem cell-derived $\mathrm{TH}+$ cells in order to test whether they behave as true matured glomus cells. TH+ cells within the neurosphere buds generated in vitro were subjected to voltage clamp using the whole-cell configuration of the patch-clamp technique. The recording in figure 6 a illustrates that the newly formed cells have small inward $\mathrm{Ca}^{2+}$ currents $\left(\mathrm{I}_{\mathrm{Ca}}\right)$ followed by larger outward $\mathrm{K}^{+}$currents $\left(\mathrm{I}_{\mathrm{K}}\right)$. The amplitude, time course and voltage dependence of the outward current were similar to those recorded from cells in rat CB slices or after enzymatic dispersion [17, 76]. As in normal CB glomus cells, blockade of the $\mathrm{K}^{+}$outward current with internal $\mathrm{Cs}^{+}$revealed the presence of typical inward, non- (or slowly) inactivating $\mathrm{Ca}^{2+}$ currents (fig. 6a). The newly formed glomus cells responded to hypoxia with an acute surge of catecholamine secretion indistinguishable from that evoked in the $\mathrm{CB}$ in vivo (fig. 6b) and they also expressed GDNF mRNA, a trophic factor characteristic of adult glomus cells (fig. 6c) [15, 76]. These data indicate that $\mathrm{TH}+$ cells derived in vitro from $\mathrm{CB}$ progenitors exhibit the characteristic complex functional properties of mature glomus cells [1]. 

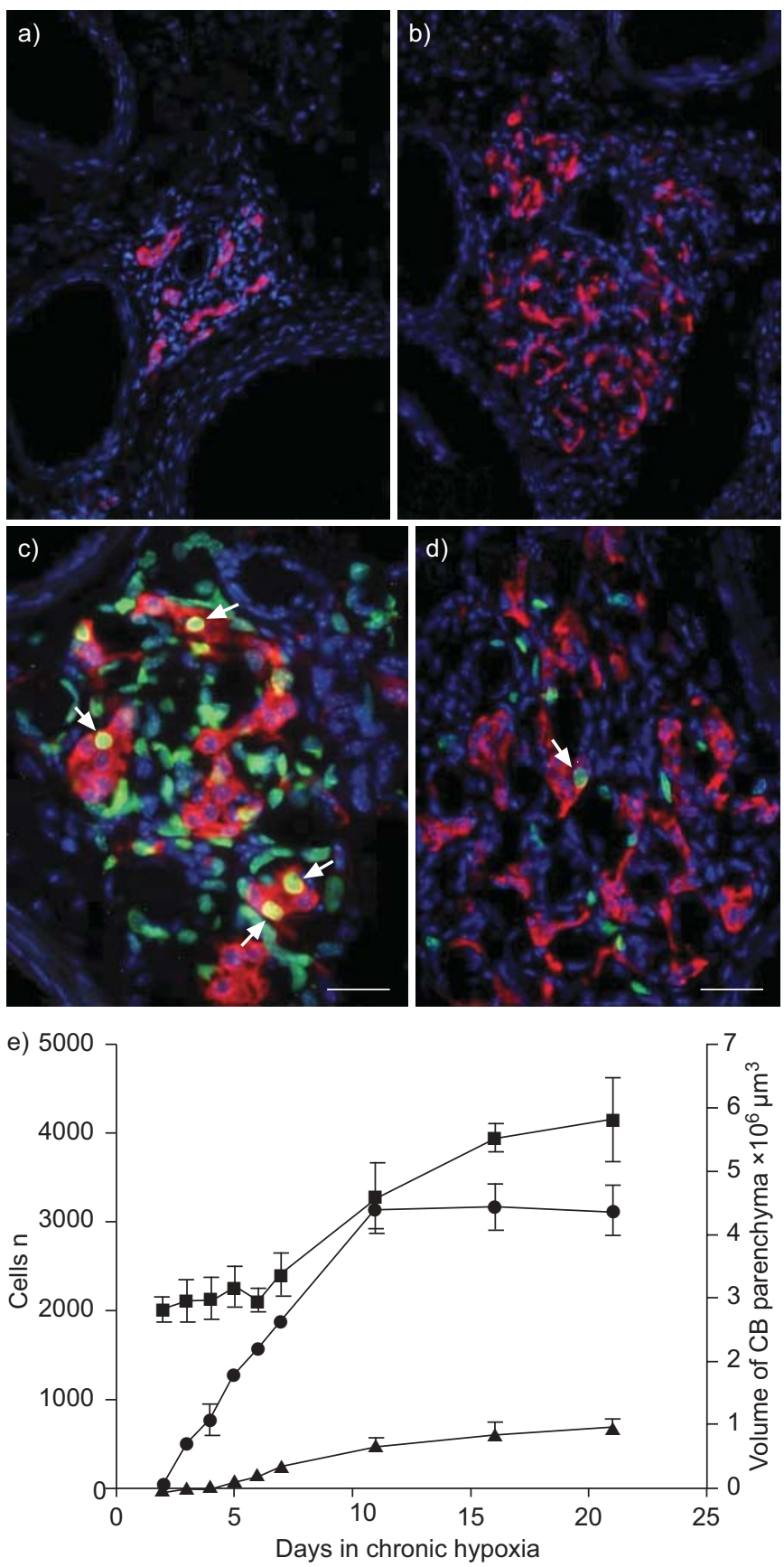

FIGURE 4. Carotid body (CB) growth in chronic hypoxia. Increase of CB size in a mouse exposed to hypoxia $\left(10 \% \mathrm{O}_{2}\right)$ for 21 days (b), compared with normoxia (a). c) Tyrosine hydroxylase $(\mathrm{TH})+$ and $\mathrm{BrdU}+$ cells (arrowheads) in a mouse $\mathrm{CB}$ exposed to hypoxia for 7 days. BrdU was administered each day from the beginning of exposure to hypoxia. d) $\mathrm{TH}+$ and $\mathrm{BrdU}+$ cells (arrows) in a mouse $\mathrm{CB}$ exposed to hypoxia for 7 days. A pulse of $\mathrm{BrdU}$ (in d) was administered $2 \mathrm{~h}$ before animal sacrifice. Cell nuclei are stained with 4',6-diamidino-2-phenylindole. TH+ cells are shown as red, and BrdU+ as green. Scale bars $=50 \mu \mathrm{m}$. e) Progressive changes of mouse $\mathrm{CB}$ cell number and volume during exposure to hypoxia. - : volume; $\bullet$ : BrdU+ cells; $\mathbf{\Delta}: \mathrm{TH}+\mathrm{BrdU}+$ cells. Reproduced and modified from [1] with permission from the publisher.

Altogether, the data summarised in the present section indicate that the adult $\mathrm{CB}$ is a neurogenic niche where new neuron-like glomus cells can derive from progenitors. In fact, this is the first example of neural crest-derived stem cells with a recognisable function identified in the adult peripheral nervous system. Based on numerous cell fate experiments both in vivo and in vitro [1], the current authors have proposed the model for neurogenesis depicted in figure $6 \mathrm{~d}$. Rat glial fibrillary acidic protein (GFAP)-positive type-II cells are viewed as quiescent (or slowly dividing) CB stem cells that can be reversibly converted to nestin+ intermediate progenitors. Upon exposure to hypoxia, the equilibrium is displaced towards the nestin+ population, giving rise to $\mathrm{TH}+$ glomus cells. Therefore, the adult CB is a well-identified neurogenic centre that can be used for research on the molecular mechanisms of neurogenesis. Knowledge on CB stem cell physiology could also facilitate the expansion of human CBs for use in cell therapy (see section Carotid body function and mechanisms of disease).

\section{CAROTID BODY FUNCTION AND MECHANISMS OF DISEASE}

The CB is mainly known for its role in the control of respiration; nevertheless, it also has increasing clinical significance, as there is mounting evidence that CB dysfunction is involved in the pathophysiology of several human diseases, some of them of high prevalence.

\section{Pathologies associated with primary alterations of carotid body $\mathrm{O}_{2}$ sensing}

CB sensitivity to hypoxia develops during the early postnatal period and this correlates with an enhanced $\mathrm{Ca}^{2+}$ rise in response to hypoxia and increase in $\mathrm{K}^{+}$current amplitude. Maturation of $\mathrm{CB}$ chemosensitivity is particularly important in the newborn since, in addition to increasing ventilation and sympathetic tone, activation of the CBs facilitates arousal from sleep and switch from nasal to oral breathing. Loss of chemosensitivity due to $\mathrm{CB}$ denervation around the time of birth produces severe respiratory disturbances in rats, piglets and lambs, exposing the newborn to respiratory instability and unexpected death [77]. In several animal species, however, the hyperventilatory response to hypoxia, abolished by $\mathrm{CB}$ denervation, is re-established totally or partially several months after the surgery (possibly due to activation of other chemoreceptors). In contrast, glomectomy due to tumour surgery in humans results in complete and sustained lack of hypoxia responsiveness [78]. Asthmatic humans treated by bilateral $\mathrm{CB}$ ablation have blunted responses to hypoxia, mainly during sleep, and some have died suddenly and unexpectedly [79].

It is believed that some respiratory disorders of the newborn, such as the sudden infant death syndrome (SIDS) could be due to primary alterations of the $C B$ chemoreceptors [80, 81]. Abnormalities in CB size or transmitter content have been reported in victims of SIDS. A common histological finding in CB from SIDS patients is the overgrowth of sustentacular/ progenitor cells with decrease of glomus cell number [82, 83]. Glomus cells from patients affected by SIDS contain a lesser number of dense core vesicles and appear to have higher $C B$ dopamine content (released to the extracellular medium) than in normal children [84]. This could be a cause of $C B$ hypochemosensitivity, as dopamine is known to inhibit $\mathrm{Ca}^{2+}$ currents in glomus cells [10]. Nicotine acting on peripheral 

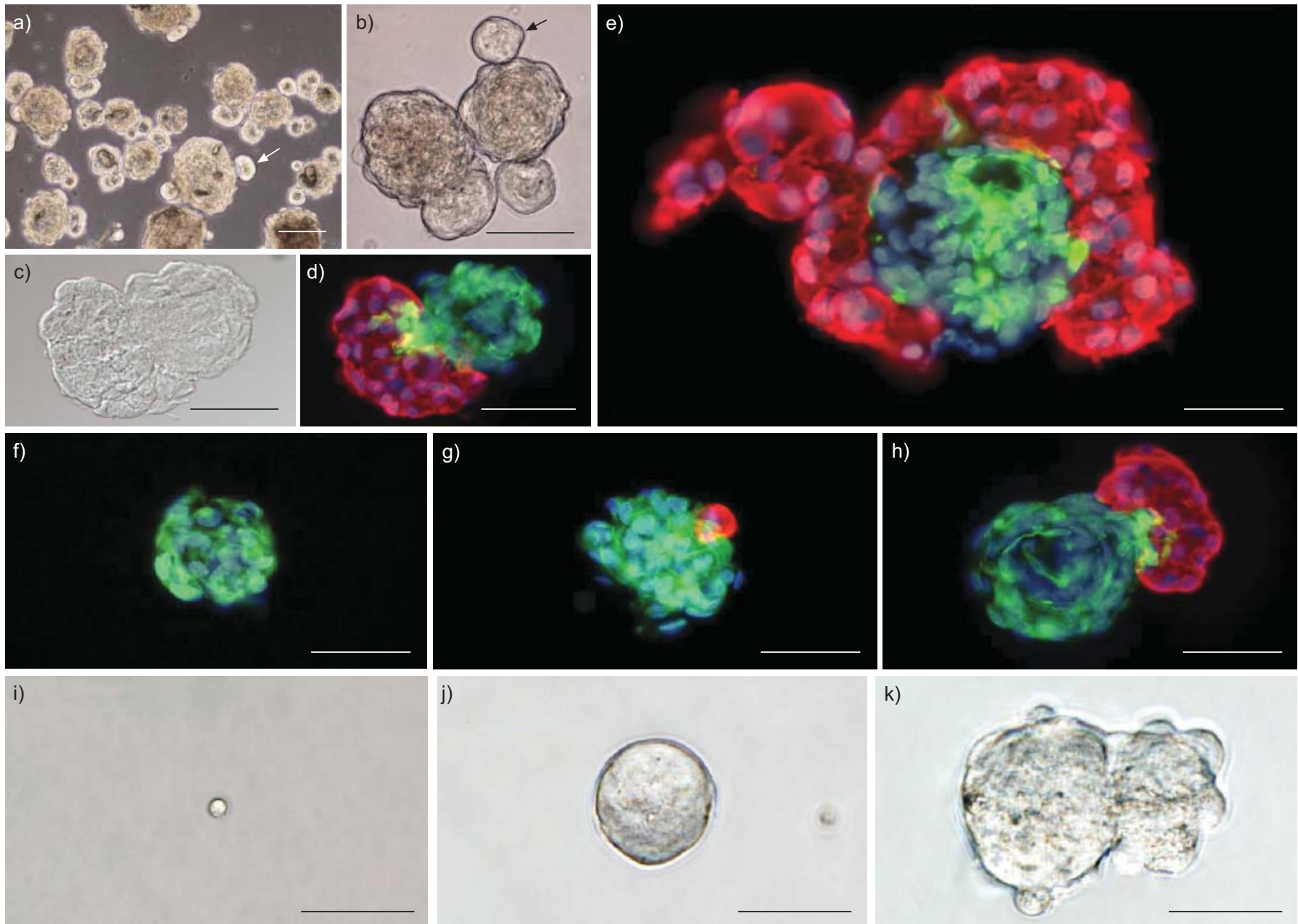

FIGURE 5. Carotid body (CB) stem cells. a) Neurospheres formed by dispersed CB cells after 10 days in culture; b) examples of the typical blebs (arrows) emerging from the neurospheres. Immunohistochemical analysis of a neurosphere thin section with bright field representation (c), and illustrating the presence of nestin+ progenitors (green) within the neurosphere core, and tyrosine hydroxylase (TH)+ glomus cells (red) within the bleb (d). e) Grown neurosphere (20 days in culture) with large blebs containing differentiated TH+ cells. Time course of rat CB neurosphere formation: f) 5 days; g) 7 days; h) 10 days. Organisation of the neurosphere core containing nestin+ progenitors precedes the appearance of $\mathrm{TH}+$ glomus cells. Sequential photographs of a clonal colony illustrating the formation of a typical $\mathrm{CB}$ neurosphere from a single $\mathrm{CB}$ stem cell: i) 0 days; j) 5 days; $k$ ) 10 days. Scale bars $=100 \mu \mathrm{m}$ ( $a$ and b) and $50 \mu \mathrm{m}$ (c-k). Modified and reproduced from [1] with permission from the publisher.

chemoreceptors may delay $\mathrm{CB}$ resetting after birth and attenuate the protective chemoreflex response, thus increasing vulnerability to hypoxic episodes in the newborn. This could explain the association between maternal smoking and SIDS syndrome [85]. It has been suggested that SIDS is probably not a sudden event but may be preceded by a relatively long period of hypoxia due to failure of reflex mechanisms [86]. More recently, vascular endothelial growth factor, a gene induced by chronic hypoxia, was found increased in cerebrospinal fluid of infants who died of SIDS as compared with controls [87], thus further supporting the view that SIDS is caused by a decreased sensitivity of chemoreceptors.

The congenital central hypoventilation syndrome (CCHS) is a life-threatening disorder with impaired ventilatory response to hypoxia and hypercapnia that as SIDS appears to be also related to $\mathrm{CB}$ dysfunction. In some CCHS patients, necropsy showed $>50 \%$ decrease in the number of $\mathrm{TH}+\mathrm{CB}$ glomus cells, increase in sustentacular cells and decrease in the number of dopaminergic vesicles [88]. Numerous cases of CCHS are associated with genetic mutations. Mutations inherited from one of the parents have been found in the coding regions of endothelin-1, brain-derived neurotrophic factor and receptor tyrosine kinase (RET). All of these genes participate in development of neural crest-derived tissues [89]. Mutations in the tyrosine kinase domain of RET are particularly interesting, since they also appear in Hirschsprung's disease, which is associated with $\sim 20 \%$ of the cases of CCHS. RET is part of the multicomponent receptor complex of GDNF, and both RET and GDNF are highly expressed in CB cells [14, 15]. A recent study has shown heterozygous de novo mutations in PHOX2B, another gene necessary for the early development of neural crest-derived cells and for the formation of reflex circuits in the autonomic nervous system, in 18 out of 29 individuals with CCHS [90, 91]. These data suggest that alteration of $\mathrm{CB}$ development and function is also associated 
a)

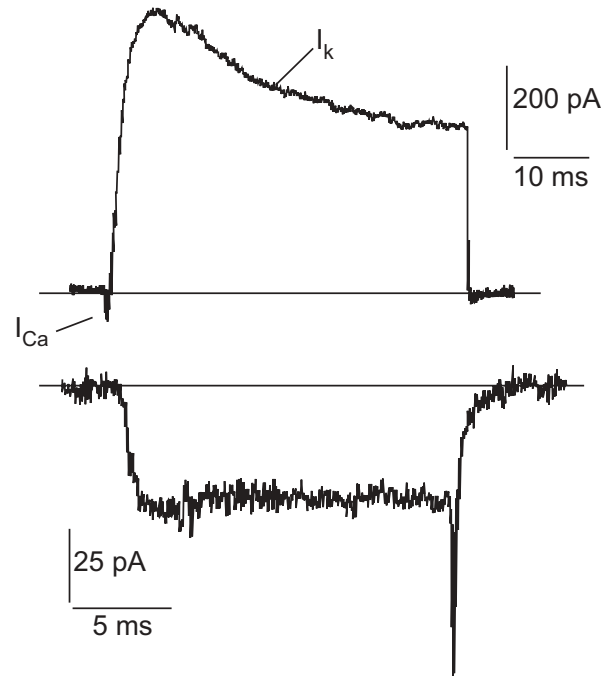

b)

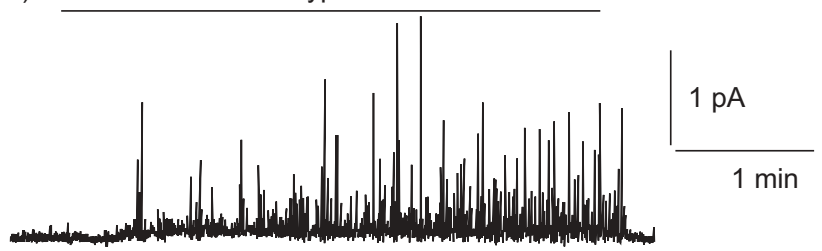

c)

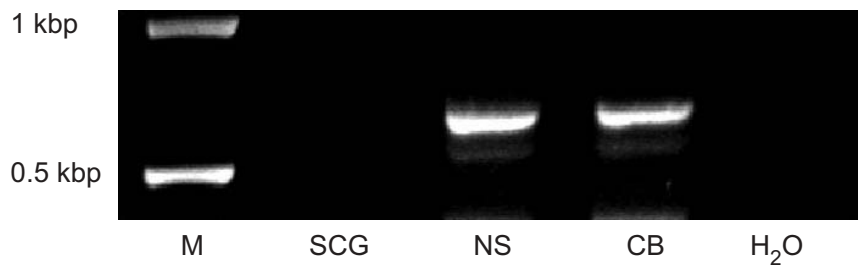

d)

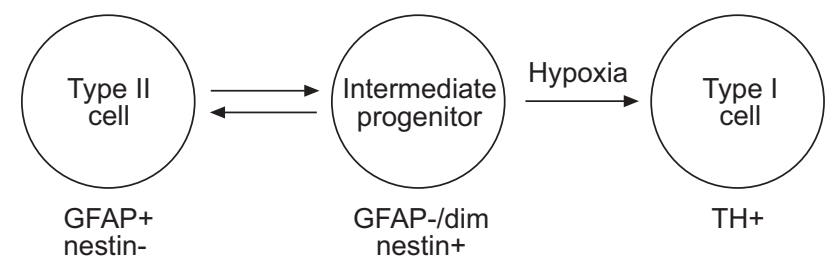

FIGURE 6. Physiological properties of in vitro differentiated glomus cells. a) Recording of calcium ( $\left.\mathrm{I}_{\mathrm{Ca}}\right)$ and potassium $\left(\mathrm{I}_{\mathrm{K}}\right)$ voltage-dependent currents obtained from a patch-clamped glomus cell in a neurosphere bleb: depolarisation from $-80 \mathrm{mV}$ to $+20 \mathrm{mV}$ (top). Patch-clamp recording of voltage-gated calcium currents after blockade of potassium channels with intracellular caesium ions (bottom). b) Glomus cell catecholamine secretory response to hypoxia (switching from a solution with $\mathrm{O}_{2}$ tension of $145 \mathrm{mmHg}(19.3 \mathrm{kPa})$ to another with $\sim 15 \mathrm{mmHg}(2.0 \mathrm{kPa}))$. Each spike represents a single exocytotic event. C) RTPCR analysis of rat carotid body (CB), superior cervical ganglion (SCG) and CBderived neurospheres (NS) to show the selective expression of glia cell line-derived neurotrophic factor mRNA. M: marker. d) Hypothetical sequence of cellular events occurring within the carotid body during exposure to hypoxia. Glial fibrillary acidic protein (GFAP)+ type-Il cells are considered to be the progenitors activated by hypoxia to produce nestin+ cells, which give rise to tyrosine hydroxylase $(T H)+$ glomus cells. Modified and reproduced from [1] with permission from the publisher. with genetic CCHS. Hence, it could be that primary alterations of the $\mathrm{CB}$ germinal niche are a major cause of respiratory reflex dysfunction seen in CCHS and SIDS patients.

Hypoventilation in adults with chronic obstructive pulmonary disease results in "blue bloaters", while those with normal ventilation are termed "pink puffers". Offspring of the blue bloaters have a poorer ventilatory response to hypoxia than offspring of pink puffers, suggesting a familial component [4]. The genetic influence on $\mathrm{CB}$ function is clear in two strains of rats, which had different $\mathrm{CB}$ calcium responses to acute hypoxia and different carotid sinus nerve traffic [92]. The respiratory stimulant, doxapram, mimics the effect of hypoxia by inhibiting both voltage- and $\mathrm{Ca}^{2+}$-dependent $\mathrm{K}^{+}$currents in glomus cells [93], providing further evidence of the importance of $\mathrm{K}^{+}$channels in $\mathrm{O}_{2}$ sensing.

\section{Carotid body and pathophysiology of chronic hypoxia}

Exposure to chronic hypoxia, e.g. living at high altitude, produces a compensatory $\mathrm{CB}$ hypertrophy and cellular hyperplasia (see section Carotid body plasticity in chronic hypoxia: adult carotid body stem cells). The same occurs in situations in which alveolar gas exchange is compromised as, for example, in cystic fibrosis or cyanotic heart disease [74, 75]. In these patients, stimulation of the respiratory centre by $\mathrm{CB}$ fibres is necessary to maintain the respiratory drive; thus, special precaution must be taken in the management of the patients to avoid excessive oxygenation and inhibition of $\mathrm{CB}$ activity. CB hypertrophia and cellular hyperplasia/anaplasia is also observed in CB tumours (chemodectomas or paragangliomas). These are relatively rare, mostly benign tumours in the neck that, besides the symptoms due to local compression, can also produce systemic hypertension [55]. The most frequent cause of chemodectoma is the hereditary $\mathrm{CB}$ paraganglioma due to mutations in SDHD, a gene that encodes the small membrane anchoring subunit of SDHD in the mitochondrial complex II [50]. The histological similarity between the CB growth in chronic hypoxia and paraganglioma has led to the suggestion that mitochondrial complex II participates in $\mathrm{O}_{2}$ sensing. As discussed previously (in the Mechanisms of carotid body acute oxygen sensing section), heterozygous SDHD knockout mice show a mild CB hypertrophy without alteration in acute responsiveness to lowering $\mathrm{O}_{2}$ tension [56]. The grade of malignancy of CB paraganglioma is inversely associated with the number of GFAP+ type-II cells, a fact that could indicate that deregulation of $\mathrm{CB}$ progenitors (with typeII cell phenotype) participates in tumorigenesis [1].

An important health problem related to $\mathrm{CB}$ function is obstructive sleep apnoea syndrome (OSAS) [94]. OSAS is a highly prevalent problem occurring at rates of $2-3 \%$ in children, $3-7 \%$ in middle-aged adults and $10-15 \%$ in healthy elderly subjects [95]. It also has 30\% prevalence among patients with socalled essential hypertension. CB seems to play a critical role in the development of hypertension associated with sleep apnoea. In rats exposed to 30 days of intermittent hypoxia ( $7 \mathrm{~h}$ per day), hypertension was observed but surgical denervation of peripheral chemoreceptors prevented the increase in arterial blood pressure. Adrenal demedullation and chemical destruction of the peripheral sympathetic nervous system by $6-\mathrm{OH}$ dopamine also prevented hypertension $[96,97]$. In patients suffering from OSAS there is an increase in sympathetic activity, probably due 
to the recurrent arousal following the periods of apnoeas. However, it is believed that hypoxia per se also increases the sympathetic tone. Intermittent hypoxia in rats induces plastic changes in the $\mathrm{CB}$, thus increasing its sensitivity and tonic sympathetic activation without obvious morphological alterations $[62,98]$. Similarly, OSAS patients have enhanced peripheral chemoreflex sensitivity and in those who experience repetitive hypoxaemia this increase might contribute to high levels of sympathetic activity even during normoxic daytime wakefulness $[99,100]$.

\section{Carotid body and cell therapy}

As the carotid body is a highly dopaminergic organ, it has been used in dopaminergic cell replacement for Parkinson's disease. Additional advantages of the carotid body for cell therapy rely on its survival in hypoxic environments, similar to that existing in the brain parenchyma after a tissue graft, and because it offers the possibility of autotransplantation in humans. Carotid body cell aggregates have been transplanted with excellent functional recovery in parkinsonian rats [101, 102] and monkeys [103]. In a safety pilot study performed on PD patients, carotid body autotransplantation produced a clear amelioration in some cases [104]. The beneficial effects of carotid body transplants are not only due to the local release of dopamine but also to a trophic action exerted on nigrostriatal dopaminergic neurons [14]. The carotid body contains more glia cell line-derived neurotrophic factor than any other structure in adult mice [15]. Therefore, glomus cells are ideal candidates to be used as biological pumps for the controlled endogenous release of glia cell line-derived neurotrophic factor and possibly other trophic factors with unique synergistic actions. In fact, carotid body grafting has also been shown to reduce neuronal death in an acute rat stroke model [105]. The systematic clinical applicability of carotid body dopamine- and glia cell line-derived neurotrophic factor-producing cells is under investigation $[1,106]$.

\section{REFERENCES}

1 Pardal R, Ortega-Saenz P, Duran R, Lopez-Barneo J. Glialike stem cells sustain physiologic neurogenesis in the adult mammalian carotid body. Cell 2007; 131: 364-377.

2 López-Barneo J, Pardal R, Ortega-Sáenz P. Cellular mechanism of oxygen sensing. Annu Rev Physiol 2001; 63: 259-287.

3 Peers C, Buckler KJ. Transduction of chemostimuli by the type I carotid body cell. J Membr Biol 1995; 144: 1-9.

4 Weir EK, López-Barneo J, Buckler KJ, Archer SL. Acute oxygen-sensing mechanisms. N Engl J Med 2005; 353: 2042-2055.

5 Campanucci VA, Zhang M, Vollmer C, Nurse CA. Expression of multiple $\mathrm{P} 2 \mathrm{X}$ receptors by glossopharyngeal neurons projecting to rat carotid body $\mathrm{O}_{2}$-chemoreceptors: role in nitric oxide-mediated efferent inhibition. J Neurosci 2006; 26: 9482-9493.

6 Nurse C. Neurotransmission and neuromodulation in the chemosensory carotid body. Auton Neurosci 2005; 120: 1-9.

7 Ureña J, López-López J, González C, López-Barneo J. Ionic currents in dispersed chemoreceptor cells of the mammalian carotid body. J Gen Physiol 1989; 93: 979-999.
8 Ureña J, Fernández-Chacón R, Benot AR, Alvarez de Toledo G, López-Barneo J. Hypoxia induces voltagedependent $\mathrm{Ca}^{2+}$ entry and quantal dopamine secretion in carotid body glomus cells. Proc Natl Acad Sci USA 1994; 91: 10208-10211.

9 Montoro RJ, Ureña J, Fernández-Chacón R, Alvarez de Toledo G, López-Barneo J. Oxygen sensing by ion channels and chemotransduction in single glomus cells. J Gen Physiol 1996; 107: 133-143.

10 Benot A, Lopez-Barneo J. Feedback inhibition of $\mathrm{Ca}^{2+}$ currents by dopamine in glomus cells of the carotid body. Eur J Neuroci 1990; 2: 809-812.

11 Zhang M, Zhong H, Vollmer C, Nurse CA. Co-release of ATP and ACh mediates hypoxic signalling at rat carotid body chemoreceptors. J Physiol 2000; 525: 143-158.

12 Nurse CA, Vollmer C. Role of basic FGF and oxygen in control of proliferation, survival, and neuronal differentiation in carotid body chromaffin cells. Dev Biol 1997; 184: 197-206.

13 Nosrat CA, Tomac A, Lindqvist E, et al. Cellular expression of GDNF mRNA suggests multiple functions inside and outside the nervous system. Cell Tissue Res 1996; 286: 191-207.

14 Toledo-Aral JJ, Méndez-Ferrer S, Pardal R, Echevarría M, López-Barneo J. Trophic restoration of the nigrostriatal dopaminergic pathway in long-term carotid body-grafted parkinsonian rats. J Neurosci 2003; 23: 141-148.

15 Villadiego J, Mendez-Ferrer S, Valdes-Sanchez T, et al. Selective glial cell line-derived neurotrophic factor production in adult dopaminergic carotid body cells in situ and after intrastriatal transplantation. J Neurosci 2005; 25: 4091-4098.

16 Duchen MR, Caddy KWT, Kirby GC, Patterson DL, Ponte J, Biscoe TJ. Biophysical studies of the cellular elements of the rabbit carotid body. Neuroscience 1988; 26: 291-311.

17 Pardal R, López-Barneo J. Low glucose-sensing cells in the carotid body. Nature Neurosci 2002; 5: 197-198.

18 López-Barneo J, López-López JR, Ureña J, González C. Chemotransduction in the carotid body: $\mathrm{K}^{+}$current modulated by $\mathrm{PO}_{2}$ in type I chemoreceptor cells. Science 1988; 241: 580-582.

19 Peers C. Hypoxic suppression of $\mathrm{K}^{+}$currents in type I carotid body cells: selective effect on the $\mathrm{Ca}^{2+}$-activated $\mathrm{K}^{+}$current. Neurosci Lett 1990; 119: 253-256.

20 Buckler KJ. A novel oxygen-sensitive potassium current in rat carotid body type I cells. J Physiol 1997; 498: 649-662.

21 Ganfornina MD, López-Barneo J. Single $\mathrm{K}^{+}$channels in membrane patches of arterial chemoreceptor cells are modulated by $\mathrm{O}_{2}$ tension. Proc Natl Acad Sci USA 1991; 88: 2927-2930.

22 Ortega-Sáenz P, Pascual A, Gomez-Díaz R, LópezBarneo J. Acute oxygen sensing in heme oxygenase-2 null mice. J Gen Physiol 2006; 128: 405-411.

23 Buckler KJ, Vaughan-Jones RD. Effects of hypoxia on membrane potential and intracellular calcium in rat neonatal carotid body type I cells. J Physiol 1994; 476: 423-428.

24 López-Barneo J. Oxygen and glucose sensing by carotid body glomus cells. Curr Opin Neurobiol 2003; 13: 493-499. 
25 Mochizuki-Oda N, Takeuchi Y, Matsumura K, Oosawa Y, Watanabe Y. Hypoxia-induced catecholamine release and intracellular $\mathrm{Ca}^{2+}$ increase via suppression of $\mathrm{K}^{+}$channels in cultured rat adrenal chromaffin cells. J Neurochem 1997; 69: 377-387.

26 Thompson RJ, Jackson A, Nurse CA. Developmental loss of hypoxic chemosensitivity in rat adrenomedullary chromaffin cells. J Physiol 1997; 498: 503-510.

27 Garcia-Fernandez M, Mejias R, Lopez-Barneo J. Developmental changes of chromaffin cells secretory responses to hypoxia studied in thin adrenal slices. Pflugers Arch 2007; 454: 93-100.

28 Youngson C, Nurse C, Yeger H, Cutz E. Oxygen sensing in airway chemoreceptors. Nature 1993; 365: 153-155.

29 Zhu WH, Conforti L, Czyzyk-Krzeska MF, Millhorn DE. Membrane depolarization in PC-12 cells during hypoxia is regulated by an $\mathrm{O}_{2}$-sensitive $\mathrm{K}^{+}$current. Am J Physiol 1996; 271: C658-C665.

30 Post JM, Hume JR, Archer SL, Weir EK. Direct role for potassium channel inhibition in hypoxic pulmonary vasoconstriction. Am J Physiol 1992; 262: C882-C890.

31 Yuan XJ, Goldman WF, Tod ML, Rubin LJ, Blaustein MP. Hypoxia reduces potassium currents in cultured rat pulmonary but not mesenteric arterial myocytes. Am J Physiol 1993; 264: L116-L123.

32 Ortega-Sáenz P, Pardal R, García-Fernández M, LópezBarneo J. Rotenone selectively occludes sensitivity to hypoxia in rat carotid body glomus cells. J Physiol 2003; 548: 789-800.

33 López-Barneo J, Ortega-Sáenz P, Piruat JI, GarcíaFernández M. Oxygen-sensing by ion channels and mitochondrial function in carotid body glomus cells. Novartis Found Symp 2006; 272: 54-64.

$34 \mathrm{Fu} \mathrm{XW,} \mathrm{Wang} \mathrm{D,} \mathrm{Nurse} \mathrm{CA,} \mathrm{Dinauer} \mathrm{MC,} \mathrm{Cutz} \mathrm{E.}$ NADPH oxidase is an $\mathrm{O}_{2}$ sensor in airway chemoreceptors: evidence from $\mathrm{K}^{+}$current modulation in wild-type and oxidase-deficient mice. Proc Natl Acad Sci USA 2000; 97: 4374-4379.

35 Roy A, Rozanov C, Mokashi A, et al. Mice lacking gp91 phox subunit of $\mathrm{NAD}(\mathrm{P}) \mathrm{H}$ oxidase showed glomus cell $\left[\mathrm{Ca}^{2+}\right]_{\mathrm{i}}$ and respiratory responses to hypoxia. Brain Res 2000; 872: 188-193.

36 Archer SL, Reeve HL, Michelakis E, et al. $\mathrm{O}_{2}$ sensing is preserved in mice lacking the gp91 phox subunit of NADPH oxidase. Proc Natl Acad Sci USA 1999; 96: 7944-7949.

37 He L, Chen J, Dinger B, et al. Characteristics of carotid body chemosensitivity in NADPH oxidase-deficient mice. Am J Physiol 2002; 282: C27-C33.

38 Sanders K, Sundar K, He L, Dinger B, Fidone S, Hoidal JR. Role of components of the phagocytic NADPH oxidase in oxygen sensing. J Appl Physiol 2002; 93: 1357-1364.

39 Lambeth JD, Cheng G, Arnold RS, Edens WA. Novel homologs of gp91phox. Trends Biochem Sci 2000; 25: 459-461.

40 Sanz-Alfayate G, Obeso A, Agapito MT, González C. Reduced to oxidized glutathione ratios and oxygen sensing in calf and rabbit carotid body chemoreceptor cells. J Physiol 2001; 537: 209-220.
41 Mills E, Jöbsis FF. Mitochondrial respiratory chain of carotid body and chemoreceptor response to changes in oxygen tension. J Neurophysiol 1972; 35: 405-428.

42 Duchen MR, Biscoe TJ. Relative mitochondrial membrane potential and $\left[\mathrm{Ca}^{2+}\right]_{i}$ in type I cells isolated from the rabbit carotid body. J Physiol 1992; 450: 33-61.

43 Buckler KJ, Vaughan-Jones RD. Effects of mitochondrial uncouplers on intracellular calcium, $\mathrm{pH}$ and membrane potential in rat carotid body type I cells. J Physiol 1998; 513: 819-833.

44 Wyatt CN, Buckler KJ. The effect of mitochondrial inhibitors on membrane currents in isolated neonatal rat carotid body type I cells. J Physiol 2004; 556: 175-191.

45 Archer SL, Huang J, Henry T, Peterson D, Weir EK. A redox-based $\mathrm{O}_{2}$ sensor in rat pulmonary vasculature. Circ Res 1993; 73: 1100-1112.

46 Varas R, Wyatt CN, Buckler KJ. Modulation of TASK-like background potassium channels in rat arterial chemoreceptor cells by intracellular ATP and other nucleotides. J Physiol 2007; 583: 521-536.

47 Wyatt CN, Pearson SA, Kumar P, Peers C, Hardie DG, Evans AM. Key roles for AMP-activated protein kinase in the function of the carotid body? Adv Exp Med Biol 2008; 605: 63-68.

48 Garcia-Fernandez M, Ortega-Saenz P, Castellano A, Lopez-Barneo J. Mechanisms of low-glucose sensitivity in carotid body glomus cells. Diabetes 2007; 56: 2893-2900.

49 Searle GJ, Hartness ME, Hoareau R, Peers C, Kemp PJ. Lack of contribution of mitochondrial electron transport to acute $\mathrm{O}_{2}$ sensing in model airway chemoreceptors. Biochem Biophys Res Commun 2002; 291: 332-337.

50 Baysal BE, Ferrell RE, Willett-Brozick JE, et al. Mutations in $S D H D$, a mitochondrial complex II gene in hereditary paraganglioma. Science 2000; 287: 848-851.

51 Heath D, Smith P, Jago R. Hyperplasia of the carotid body. J Pathol 1982; 138: 115-127.

52 McGregor KH, Gil J, Lahiri S. A morphometric study of the carotid body in chronically hypoxic rats. J Appl Physiol 1984; 57: 1430-1438.

53 Gimenez-Roqueplo AP, Favier J, Rustin P, et al. The R22X mutation of the SDHD gene in hereditary paraganglioma abolishes the enzymatic activity of complex II in the mitochondrial respiratory chain and activates the hypoxia pathway. Am J Hum Genet 2001; 69: 1186-1197.

54 Rustin P, Munnich A, Rötig A. Succinate dehydrogenase and human diseases: new insights into a well-known enzyme. Eur J Hum Genet 2002; 10: 289-291.

55 Baysal BE. On the association of succinate dehydrogenase mutations with hereditary paraganglioma. Trends Endocrinol Metab 2003; 14: 453-459.

56 Piruat JI, Pintado CO, Ortega-Sáenz GP, Roche M, LópezBarneo J. Mitochondrial SDHD-deficient mice show persistent carotid body glomus cell activation with full responsiveness to hypoxia. Mol Cell Biol 2004; 24: 10933-10940.

57 Semenza GL. Hydroxylation of HIF-1: oxygen sensing at the molecular level. Physiology 2004; 19: 176-182.

58 Schofield CJ, Ratcliffe PJ. Signalling hypoxia by HIF hydroxylases. Biochem Biophys Res Commun Rev 2005; 338: 617-626. 
59 Jaakkola P, Mole DR, Tian YM, et al. Targeting of HIF- $\alpha$ to the von Hippel-Lindau ubiquitylation complex by $\mathrm{O}_{2-}$ regulated prolyl hydroxylation. Science 2001; 292: 468-472.

60 Del Toro R, Levitsky KL, Lopez-Barneo J, Chiara MD. Induction of T-type calcium channel gene expression by chronic hypoxia. J Biol Chem 2003; 278: 22316-22324.

61 Kline DD, Peng YJ, Manalo DJ, Semenza GL, Prabhakar NR. Defective carotid body function and impaired ventilatory responses to chronic hypoxia in mice partially deficient for hypoxia-inducible factor $1 \alpha$. Proc Natl Acad Sci USA 2002; 99: 821-826.

62 Peng YJ, Yuan G, Ramakrishnan D, et al. Heterozygous HIF-1 deficiency impairs carotid body-mediated cardiorespiratory responses and ROS generation in mice exposed to chronic intermittent hypoxia. J Physiol 2006; 577: 705-716.

63 Ortega-Saenz P, Pascual A, Piruat JI, Lopez-Barneo J. Mechanisms of acute oxygen sensing by the carotid body: lessons from genetically modified animals. Respir Physiol Neurobiol 2007; 157: 140-147.

64 Maines MD. The hemo oxygenase system: a regulator of second messenger gases. Annu Rev Pharmacol Toxicol 1997; 37: 517-554.

65 Doré S, Takahashi M, Ferris CD, et al. Bilirubin, formed by activation of heme oxygenase-2, protects neurons against oxidative stress injury. Proc Natl Acad Sci USA 1999; 96: 2445-2450.

66 Williams SE, Wootton P, Mason HS, et al. Hemoxygenase-2 is an oxygen sensor for a calciumsensitive potassium channel. Science 2004; 306: 2093-2097.

67 Poss KD, Thomas MJ, Ebralidze AK, O'Dell TJ, Tonegawa S. Hippocampal long-term potentiation is normal in heme oxygenase-2 mutant mice. Neuron 1995; 15: 867-873.

68 Wang $\mathrm{R}, \mathrm{Wu} \mathrm{L}$. The chemical modification of $\mathrm{KCa}$ channels by carbon monoxide in vascular smooth muscle cells. J Biol Chem 1997; 272: 8222-8226.

69 Hoshi T, Lahiri S. Oxygen sensing: it's a gas! Science 2004; 306: 2050-2051.

70 Adachi T, Ishikawa K, Hida W, et al. Hypoxemia and blunted hypoxic ventilatory response in mice lacking heme-oxygenase-2. Biochem Biophys Res Commun 2004; 320: 514-522.

71 Arias-Stella J, Valcarcel J. Chief cell hyperplasia in the human carotid body at high altitudes; physiologic and pathologic significance. Hum Pathol 1976; 7: 361-373.

72 Wang, ZY, Bisgard GE., Chronic hypoxia-induced morphological and neurochemical changes in the carotid body. Microsc Res Tech 2002; 59: 168-177.

73 Edwards C, Heath D, Harris P. The carotid body in emphysema and left ventricular hypertrophy. J Pathol 1971; 104: 1-13.

74 Doetsch F, Caille I, Lim DA, Garcia-Verdugo JM, Alvarez-Buylla A. Subventricular zone astrocytes are neural stem cells in the adult mammalian brain. Cell 1999; 97: 703-716.

75 Molofsky AV, Pardal R, Iwashita T, Park IK, Clarke MF, Morrison SJ. BMI-1 dependence distinguishes neural stem cell self-renewal from progenitor proliferation. Nature 2003; 425: 962-967.
76 Pardal R, Luwewig U, García-Hirschfeld J, López-Barneo J. Secretory responses of intact glomus cells in thin slices of rat carotid body to hypoxia and tetraethylammonium. Proc Natl Acad Sci USA 2000; 97: 2361-2366.

77 Donnelly DF. Developmental aspects of oxygen sensing by the carotid body. J Appl Physiol 2000; 88: 2296-2301.

78 Timmers HJ, Wieling W, Karemaker JM, Lenders JW. Denervation of carotid baro- and chemoreceptors in humans. J Physiol 2003; 553: 3-11.

79 Sullivan CE. Bilateral carotid body resection in asthma: vulnerability to hypoxic death in sleep. Chest 1980; 78: 354

80 Naeye RL, Ladis B, Drage JS. Sudden infant death syndrome. A prospective study. Am J Dis Child 1976; 130: 1207-1210.

81 Gauda E, McLemore G, Tolosa J, Marston-Nelson J, Kwak D. Maturation of peripheral arterial chemoreceptors in relation to neonatal apnoea. Semin Neonatol 2004; 3: 181-194.

82 Heath D, Smith P, Jago R. Hyperplasia of the carotid body. J Pathol 1982; 138: 115-127.

83 Porzionato A, Macchi V, Parenti A, Matturri L, De Caro R. Peripheral chemoreceptors: postnatal development and cytochemical findings in sudden infant death syndrome. Histol Histopathol 2008; 23: 351-365.

84 Perrin DG, Cutz E, Becker LE, Bryan AC, Madapallimatum A, Sole MJ. Sudden infant death syndrome: increased carotid-body dopamine and noradrenaline content. Lancet 1984; 2: 535-537.

85 Holgert H, Hokfelt, Hertzberg T, Lagercrantz H., Functional and developmental studies of the peripheral arterial chemoreceptors in rat: effects of nicotine and possible relation to sudden infant death syndrome. Proc Natl Acad Sci USA 1995; 92: 7575-7579.

86 Rognum TO, Saugstad OD, Oyasaeter S, Olaisen B. Elevated levels of hypoxanthine in vitreous humor indicate prolonged cerebral hypoxia in victims of sudden infant death syndrome. Pediatrics 1988; 82: 615-618.

87 Jones KL, Krous HF, Nadeau J, Blackbourne B, Zielke HR, Gozal D. Vascular endothelial growth factor in the cerebrospinal fluid of infants who died of sudden infant death syndrome: evidence for antecedent hypoxia. Pediatrics 2003; 111: 358-363.

88 Cutz E, Ma TK, Perrin DG, Moore AM, Becker LE. Peripheral chemoreceptors in congenital central hypoventilation syndrome. Am J Respir Crit Care Med 1997; 155: 358-363.

89 Gaultier C, Amiel J, Dauger S, et al. Genetics and early disturbances of breathing control. Pediatr Res 2004; 55: 729-733.

90 Amiel J, Laudier B, Attié-Bitach T, et al. Polyalanine expansion and frameshift mutations of the paired-like homeobox gene PHOX2B in congenital central hypoventilation syndrome. Nat Genet 2003; 33: 459-461.

91 Dauger S, Pattyn A, Lofaso F, et al. Phox $2 \mathrm{~b}$ controls the development of peripheral chemoreceptors and afferent visceral pathways. Development 2003; 130: 6635-6642.

92 Weil J, Stevens T, Pickett C, et al. Strain-associated differences in hyoxic chemosensitivity of the carotid body in rats. Am J Physiol 1998; 274: L767-L774. 
93 Peers C. Effects of doxapram on ionic currents recorded in isolated type 1 cells of the neonatal rat carotid body. Brain Res 1991; 568: 116-122.

94 Peppard PE, Young T, Palta M, Skatrud J. Prospective study of the association between sleep-disordered breathing and hypertension. N Engl J Med 2000; 342: 1378-1384.

95 Smith CA, Nakayama H, Dempsey JA. The essential role of carotid body chemoreceptors in sleep apnea. Can J Physiol Pharmacol 2003; 81: 774-779.

96 Lesske J, Fletcher EC, Bao G, Unger T. Hypertension caused by chronic intermittent hypoxia - influence of chemoreceptors and sympathetic nervous system. J Hypertens 1997; 15: 1593-1603.

97 Fletcher EC, Lesske J, Behm R, Miller CC 3rd, Stauss H, Unger T., Carotid chemoreceptors, systemic blood pressure, and chronic episodic hypoxia mimicking sleep apnea. J Appl Physiol 1992; 72: 1978-1984.

98 Prabhakar NR, Peng YJ, Kumar GK, Pawar A. Altered carotid body function by intermittent hypoxia in neonates and adults: relevance to recurrent apneas. Respir Physiol Neurobiol 2007; 157: 148-153.

99 Narkiewicz K, van de Borne PJ, Montano N, Dyken ME, Phillips BG, Somers VK. Contribution of tonic chemoreflex activation to sympathetic activity and blood pressure in patients with obstructive sleep apnea. Circulation 1998; 97: 943-945.
100 García-Río F, Pino JM, Ramirez T, et al. Inspiratory neural drive response to hypoxia adequately estimates peripheral chemosensitivity in OSAHS patients. Eur Respir J 2002; 20: 724-732.

101 Espejo EF, Montoro RJ, Armengol JA, Lopez-Barneo J. Cellular and functional recovery of parkinsonian rats after intrastriatal transplantation of carotid body cell aggregates. Neuron 1998; 20: 197-206.

102 Hao G, Yao Y, Wang J, Zhang L, Viroonchatapan N, Wang ZZ. Intrastriatal grafting of glomus cells ameliorates behavioral defects of parkinsonian rats. Physiol Behav 2002; 77: 519-525.

103 Luquin MR, Montoro RJ, Guillen J, et al. Recovery of chronic parkinsonian monkeys by autotransplants of carotid body cell aggregates into putamen. Neuron 1999; 22: 743-750.

104 Arjona V, Mínguez-Castellanos A, Montoro RJ, et al. Autotransplantation of human carotid body cell aggregates for treatment of Parkinson's disease. Neurosurgery 2003; 53: 321-328.

105 Yu G, Xu L, Hadman M, Hess DC, Borlongan CV. Intracerebral transplantation of carotid body in rats with transient middle cerebral artery occlusion. Brain Res 2004; 1015: 50-56.

106 Mínguez-Castellanos A, Escamilla-Sevilla F, Hotton GR, et al. Carotid body autotransplantation in Parkinson disease: a clinical and positron emission tomography study. J Neurol Neurosurg Psychiatry 2007; 78: 825-831. 